\title{
HUBUNGAN USIA IBU DENGAN POLA TIDUR PADA IBU HAMIL PRIMIGRAVIDA DI PUSKESMAS PAJANG SURAKARTA
}

\section{Relationship Of Mother Age With Sleep Pattern In Primigravida Pregnant Mother In Pajang Health Center Surakarta}

\author{
Ratih Prananingrum ${ }^{1}$, Nur Hidayah ${ }^{2}$ \\ STIKES PKU MUHAMMADIYAH SURAKARTA \\ (ratihprananingrum@gmail.com)
}

\begin{abstract}
ABSTRAK
Latar Belakang : Kehamilan ideal usia 25-<35tahun. Semakin lama perut membesar sehingga membuatnya tidur posisi apapun tidak nyaman. Usia terbaik seorang wanita untuk hamil adalah 20 tahun hingga 35 tahun. Apabila seorang wanita mengalami primigravida (masa kehamilan pertama kali) di bawah usia 20 tahun, maka disebut primigravida muda.

Tujuan Penelitian : mengetahui hubungan usia ibu dan pola tidur dengan loving massage in pregnancy pada ibu hamil

Metode : Metode penelitian korelasi pearson Sample 21. Data usia diperoleh dari kuesioner. Data dianalisis uji Rank Spearman.

Hasil : Hasil penelitian dan uji statistik tidak ada hubungan yang berarti antara usia ibu dan Pola Tidur dengan Loving Massage In Pregnancy Pada Ibu Hamil ( $>0,05$ dan $\mathrm{p}=0.104$ ). Penelitian mendapatkan perijinan KEPK FK UMS No.1183/B.2/KEPK-FKUMS/IV/2018.

Simpulan : Kesimpulan tidak ada hubungan berarti antara usia dan Pola Tidur Dengan Loving Massage In Pregnancy pada Ibu Hamil.

Kata kunci : Umur, Pola Tidur, Pijat Cinta Dalam Kehamilan
\end{abstract}

\section{ABSTRACT}

Background: Ideal pregnancy aged 25-35 years. The longer the stomach enlarges, making it sleep any uncomfortable position. The best age for a woman to get pregnant is 20 years to 35 years. If a woman experiences primigravida (first pregnancy period) under the age of 20, then it is called young primigravida.

Objective: To determine the relationship between maternal age and sleep patterns with loving massage in pregnancy in pregnant women

Method: Pearson Sample correlation research method 21. Age data obtained from the questionnaire. Data were analyzed by Rank Spearman test.

Results: The results of the study and statistical tests did not have a significant relationship between maternal age and sleep patterns with Loving Massage In Pregnancy in Pregnant Women $(p>0.05$ and $p=0.104)$. Research obtains KEPK FK UMS licensing No.1183 / B.2 / KEPK-FKUMS / IV / 2018.

Conclusion: Conclusion there is no significant relationship between age and Sleep Pattern with Loving Massage In Pregnancy in Pregnant Women.

Keywords: Age, Sleep Pattern, Massage of Love in Pregnancy 


\section{PENDAHULUAN}

Salah satu kebutuhan dasar manusia adalah istirahat dan tidur. Istirahat dan tidur diperlukan agar otak dan tubuh dapat memperbaiki dirinya sendiri, sehingga bila seseorang kurang tidur akan segera tampak berbagai kelainan fisik maupun mental. Pada saat tidur kerja tubuh melambat, sehingga membuat sel-sel penyembuh untuk memperbaiki sel-sel yang rusak (Prasadja, 2009). Usia terbaik seorang wanita untuk hamil adalah 20 tahun hingga 35 tahun. Apabila seorang wanita mengalami primigravida (masa kehamilan pertama kali) di bawah usia 20 tahun, maka disebut primigravida muda. Sedangkan apabila primigravida dialami oleh wanita di atas usia 35 tahun, maka disebut primigravida tua. Semakin besar/tua usia ibu hamil mengalami masalah tidur saat hamil dikarenakan banyak factor yng mengganggu. Pada saat hamil di usia muda, kualitas tidur cenderung lebih terjaga. (Barden et al., 2010).

Primigravida tua (older primigravida) adalah seorang wanita dimana mengalami kehamilan pertama pada usia lebih dari 35 tahun. Seorang primigravida tua memiliki risiko preeklamsia lebih tinggi oleh karena adanya perbedaan elastisitas dan kemunduran sistem kardiovaskuler, selain itu seorang primigravida tua memiliki kecenderungan mengalami masalah obesitas lebih tinggi dibanding primigravida muda Banyak faktor yang menyebabkan seorang wanita mengalami primigravida tua. Selain oleh karena faktor alami biologis, kini wanita karir dan terdidik banyak yang ingin hidup mandiri untuk mengejar karir sehingga akan terlambat menikah dan hamil di atas usia 35 tahun. (Asrinah, dkk. 2010). Menurut National Sleep Foundation (2007) dalam Rezaei (2015), perempuan hamil yang mengalami beberapa bentuk gangguan tidur mencapai 79\%. Sebanyak $72 \%$ dari ibu hamil akan mengalami frekuensi terbangun lebih sering pada malam hari. Umumnya kebutuhan tidur orang dewasa yakni selama 7-8 jam, namun untuk ibu hamil bisa mencapai 10 jam. Hal ini tergantung pada umur saat ibu hamil dan stamina yang dirasakan ibu. Kualitas tidur yang baik akan menjaga kesehatan ibu selama hamil serta memberikan cukup energi saat persalinan. Penelitian yang dilakukan oleh Komalasari et al (2012), di Jatinangor mengenai kualitas tidur ibu hamil trimester III didapatkan hasil bahwa sebanyak $72,2 \%$ dari 54 ibu hamil yang diteliti memiliki kualitas tidur yang buruk dan terdapat hubungan yang bermakna antara tingkat kecemasan dengan kualitas tidur ibu hamil. Sejalan dengan penelitian yang dilakukan Komalasari et al (2012), penelitian yang dilakukan oleh Andari (2013), di Medan juga menunjukkan bahwa 63\% dari $41 \mathrm{ibu}$ hamil mempunyai kualitas tidur yang buruk karena perubahan fisiologis dan psikologis yang dialami ibu ketika hamil.

Prevalensi gangguan pola tidur pada saat kehamilan secara nasioanl tahun 2013 sebesar 36,5\%. Prevalensi ibu hamil primigravida trimester 1, 2 dan 3 dengan kategori sangat cemas dalam pola tidur di Jawa Tengah 15,2\% pada trimester 1, 19,6\% pda trimester 2 dan 22,8\% pada trimester 3. Prevalensi pada ibu hamil primigravida pada trimester 1,2 dan 3 mengalami peningkatan. Di Kota Surakarta prevalensi ibu hamil primigravida dengan gangguan pola tidur pada trimester 1, 2 dan 3 sebesar 11,6\% (TM 1), 13,85\%, (TM 2) dan 16,3\% (TM 3). (Riskesdas, 2013) 
Salah satu cara yang berpengaruh terhadap gangguan pola tidur pada ibu hamil primigravida adalah loving massase in pregnancy. Loving massase adalah salah satu terapi holistic yang diawali dengan relaksasi pernafasan kemudian berdoa kepada Tuhan memohon kesejahteraan body, mind, dan spirit, dilanjutkan dengan memunculkan rasa peduli, mencintai dan penuh kasih pemijat pada ibu dengan tulus. Teknik pijat dilakukan dengan cara efflurage, petrissage, accuspressure dan love kneading pada bagian tubuh tertentu untuk meningkatkan sirkulasi dan relaksasi. (Richards K. C., Gibson, R., \& OvertoonMcCoy, A. L. 2009). Penelitian dilakukan di Kota Surakarta yang memiliki tingkat kepadatan penduduk tinggi. Dimana usia referensi usia ibu hamil semakin tua maka pola tidur akan semakin terganggu yang berdampak pada kehidupan ibu hamil tersebut. Di Surakarta prevalensi ibu hamil primigravida dengan gangguan pola tidur pada trimester 1, 2 dan 3 sebesar 11,6\% (TM 1), 13,85\% (TM 2) dan 16,3\% (TM 3) Tingginya angka ini menunjukkan bahwa pola tidur pada ibu hamil di daerah perkotaan di wilayah Surakarta telah tersebar luas (Hidayati, 2010).

Tujuan penelitian ini untuk mengetahui hubungan usia ibu dan pola tidur dengan loving massage in pregnancy pada ibu hamil.

\section{METODE PENELITIAN}

Metode penelitian ini menggunakan korelasi pearson merupakan salah satu ukuran korelasi yang digunakan untuk mengukur kekuatan dan arah hubungan linier dari dua variabel.Sample penelitian sebanyak $21 \mathrm{ibu}$ hamil primigravida. Data usia ibu diperoleh dari hasil kuesioner yang diisi sebelum dilakukan pemijatan. Data dianalisis menggunakan uji Rank Spearman.

\section{HASIL DAN PEMBAHASAN}

Tabel 1. Distribusi Frekuensi Usia Ibu Hamil Primigravida dan Pola Tidur

Case Processing Summary

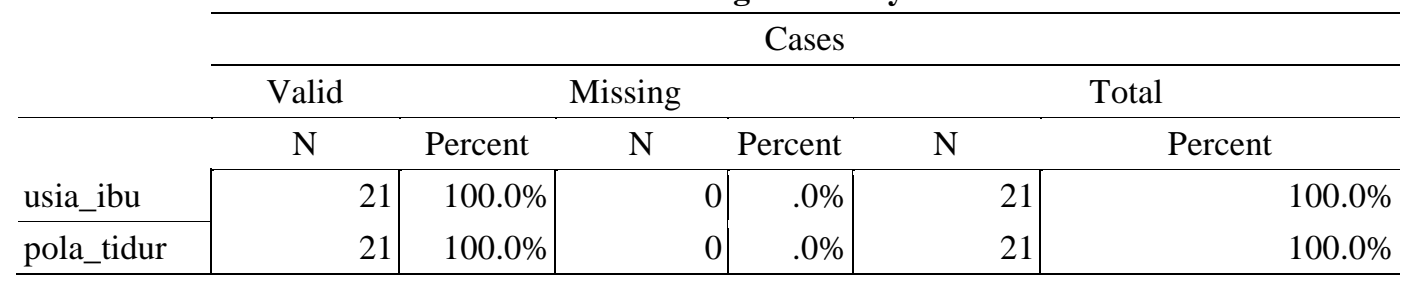


Avicenna Journal of Health Research. Vol 1 No 2. Oktober $2018(38-43)$

\section{Descriptives}

\begin{tabular}{|c|c|c|c|c|}
\hline & & & Statistic & Std. Error \\
\hline \multirow[t]{13}{*}{ usia_ibu } & Mean & & 25.2381 & .68280 \\
\hline & \multirow{2}{*}{$\begin{array}{l}95 \% \text { Confidence Interval for } \\
\text { Mean }\end{array}$} & Lower Bound & 23.8138 & \\
\hline & & Upper Bound & 26.6624 & \\
\hline & $5 \%$ Trimmed Mean & & 25.0503 & \\
\hline & Median & & 25.0000 & \\
\hline & Variance & & 9.790 & \\
\hline & Std. Deviation & & 3.12897 & \\
\hline & Minimum & & 19.00 & \\
\hline & Maximum & & 35.00 & \\
\hline & Range & & 16.00 & \\
\hline & Interquartile Range & & 2.50 & \\
\hline & Skewness & & 1.217 & .501 \\
\hline & Kurtosis & & 4.341 & .972 \\
\hline \multirow[t]{13}{*}{ pola_tidur } & Mean & & 14.0000 & .24881 \\
\hline & \multirow{2}{*}{$\begin{array}{l}95 \% \text { Confidence Interval } \\
\text { for Mean }\end{array}$} & Lower Bound & 13.4810 & \\
\hline & & Upper Bound & 14.5190 & \\
\hline & $5 \%$ Trimmed Mean & & 14.0026 & \\
\hline & Median & & 14.0000 & \\
\hline & Variance & & 1.300 & \\
\hline & Std. Deviation & & 1.14018 & \\
\hline & Minimum & & 12.00 & \\
\hline & Maximum & & 16.00 & \\
\hline & Range & & 4.00 & \\
\hline & Interquartile Range & & 2.00 & \\
\hline & Skewness & & -.224 & .501 \\
\hline & Kurtosis & & -1.031 & .972 \\
\hline
\end{tabular}

Tests of Normality

\begin{tabular}{|c|c|c|c|c|c|c|c|}
\hline & \multicolumn{4}{|c|}{ Kolmogorov-Smirnov $^{\mathrm{a}}$} & \multicolumn{2}{|c|}{ Shapiro-Wilk } & \multirow[b]{2}{*}{ Sig. } \\
\hline & Statistic & df & & Sig. & Statistic & df & \\
\hline $\begin{array}{l}\text { usia } \\
\text { ibu }\end{array}$ & .213 & & 21 & .014 & .886 & 21 & .019 \\
\hline pola_tidur & .238 & & 21 & .003 & .889 & 21 & .022 \\
\hline
\end{tabular}

a. Lilliefors Significance Correction 
Tabel 2. Analisa Bivariat Hubungan antara usia dan Pola Tidur Dengan Loving Massage In Pregnancy pada Ibu Hamil.

\begin{tabular}{llcc}
\multicolumn{4}{c}{ Correlations } \\
\hline Usia & Pearson Correlation & usia_ibu & pola_tidur \\
ibu & Sig. (2-tailed) & 1 & -.364 \\
& $\mathrm{~N}$ & 21 & .104 \\
\multirow{3}{*}{ Pola tidur } & Pearson Correlation & -.364 & 21 \\
& Sig. (2-tailed) & .104 & 1 \\
& $\mathrm{~N}$ & 21 & 21 \\
\hline
\end{tabular}

Hasil penelitian menunjukkan tidak ada ada hubungan yang berarti antara usia ibu dan Pola Tidur Dengan Loving Massage In Pregnancy Pada Ibu Hamil (p> 0,05). Hasil uji statistik menunjukkan bahwa usia ibu hamil tidak memiliki hubungan dengan pola tidur mengenai hubungan usia ibu dan pola tidur $(\mathrm{p}=0.104)$.

\section{SIMPULAN DAN SARAN}

\section{Simpulan}

Simpulan penelitian ini adalah tidak ada hubungan yang berarti usia dan Pola Tidur Dengan Loving Massage In Pregnancy pada Ibu Hamil dikarenakan kehamilan pertama yang dirasakan ibu masih bisa diatasi dengan loving massage dan ibu masih belum ada kesibukan lainnya seperti masih fokus dengan kehamilannya, belum momong anak pertamanya, kehamilan yang sangat membahagiakan, kehamilan yang pasti sangat dinanti dan ibu berusaha untuk menjaga pola tidurnya. Sehingga usia ibu hamil yang mengandung anak pertamanya (primigravida) tidak mengganggu pola tidur ibu.

\section{Saran}

Saran yang dapat disampaikan yaitu walaupun usia ibu tidak mengganggu pola tidur dengan loving massage in pregnancy, sebaiknya usia ibu apabila mengalami kehamilan tidak terlalu tua dan tidak terlalu tua. Sebab kematian ibu hamil dipicu oleh kondisi kehamilan yang tidak ideal yang disebut ' 4 Terlalu' yakni: Kehamilan terlalu muda (kurang dari 18 tahun). Usia yang terlalu tua untuk hamil (di atas 34 tahun), Jarak kehamilan terlalu dekat (kurang dari 2 tahun), Kehamilan terlalu banyak (lebih dari 3 anak).

\section{DAFTAR PUSTAKA}

Andari (2013), Kualitas Tidur dan Pola Tidur Pada Ibu Hamil Trimester III yang Memeriksakan Kehamilan di Klinik Mariyati Lbuhan Deli Kecamatan Medan Marelan. Sumatera Utara : Fakultas Ilmu Keperawatan Asrinah,dkk.2010.Asuhan Kebidanan Masa Kehamilan.Yogyakarta:Graha Ilmu 
Asmadi. 2008. Tehnik prosedural keperawatan: Konsep dan applikasi kebutuhan dasar klien. Jakarta: Salemba Medika

Barden-O'Fallon JL \& Speizer IS 2010, Indonesian Couples' Pregnancy Ambivalence and Contraceptive Use. Int Perspect Sex Reprod Health. 36(1):36-43, https://www.ncbi.nlm.nih.gov/pubmed/20403804

Emilia,E. 2008. Pengetahuan,Sikap,dan Praktek Gizi pada Remaja. Skripsi. Bogor. Sekolah Pasca Sarjana Institut Pertanian Bogor. Bogor.

Hidayati, A. (2010). Kebutuhan Dasar Manusia, Jakarta: Salemba Medika

Komalasari et al (2012), Hubungan Tingkat Kecemasan dengan Kualitas Tidur pada Ibu hamil Trimester III di Puskesmas Jatinangor Kabupaten Sumedang (skripsi). Bandung : Fakultas Ilmu Keperawatan

Lee, C. Y. et al. (2008). Older Patients' Experiences of Sleep in the Hospital: Disruptions and Remedies. Haven of Hope Hospital and The Nethersole School of Nursing, The Chinese University of Hong kong, Shatin, N.T., Hong Kong. the Open Sleep

National Sleep Foundation. (2007). Most Common Sleep Problem in Women.

Prasadja, Andreas. 2009. Ayo Bangun! Dengan Bugar Karena Tidur yang Benar. Jakarta: Mizan

Riset Kesehatan Dasar (Riskesdas) 2013. 2013. Laporan Hasil Riset Kesehatan Dasar (Riskesdas) 2010. Jakarta: Badan Litbangkes, Depkes RI.

Richards K. C., Gibson, R., \& OvertoonMcCoy, A. L. (2009).Effects of massage in acute and critical care. AmericanAssociation of Critical Care Nurses. 